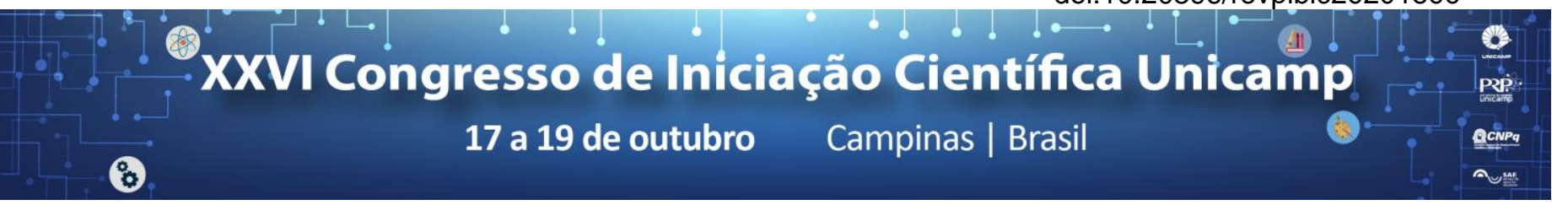

\title{
Remoção de compostos nitrogenados por processo ANAMMOX em filtro biológico percolador
}

\author{
Alef F. da Costa*, Rosana O. Menezes, Rafael de A. Neves, Luana M. O. Cruz.
}

\section{Resumo}

Neste projeto foi contruído um reator em escala de bancada do tipo Filtro percolador sem recirculação para avaliar o seu desempenho quanto a remoção de compostos nitrogenados pelo processo anammox. Além disso, foram realizados testes de tempo de detenção hidráulico (TDH), caracterização do meio suporte e da biomassa utilizada como inóculo. O reator foi alimentado com esgoto sintético durante 3 meses. O TDH teórico foi próximo ao encontrado no teste prático (60 min); o índice de vazios do meio suporte foi de $84 \%$ e a média de remoção de nitrogênio total foi igual a $15 \%$. Detaca-se que a dificuldade para controlar a entrada de oxigênio dissolvido junto com o afluente diminuiu a capacidade de remoção de compostos nitrogenados pelo reator.

\section{Palavras-chave:}

esgoto, saneamento, meio suporte de espuma.

\section{Introdução}

O despejo de efluentes em corpos hídricos sem remoção de nitrogênio pode causar diversos problemas, como a eutrofização de rios e redução do oxigênio dissolvido pelo crescimento de algas. Este trabalho tem como objetivo o estudo da remoção de compostos nitrogenados, via processo anammox, por filtro percolador preenchido com espumas de poliuretano como meio suporte (Figura 1). Operou-se um reator de acrílico em escala de bancada alimentado com esgoto sintético o qual foi monitorado semanalmente. Seu desempenho foi verificado pela remoção de nitrogênio nas formas de nitrito e amônia que eram inseridos nas concentrações (em termos de nitrogênio total) próximas ao esgoto doméstico. Os resultados apresentaram variações devido a alterações e dificuldades na padronização do esgoto sintético e por nitrificação devido à dificuldade de controle do oxigênio. A remoção média de nitrogênio total, nos 3 primeiros meses de operação, foi igual a 15\%.

\section{Resultados e Discussão}

O Tempo de Retenção Hidráulico (TDH) teórico foi próximo ao valor encontrado para o seu teste pelo método do degrau, alcançando 60 minutos. $\mathrm{Na}$ caracterização de meio suporte avaliou -se a umidade relativa aproximadamente $0 \%$, índice de vazios $84 \%$ e índice de acomodação $12 \%$. O inóculo também foi caracterizado, obtendo -se uma média de concentração de Sólidos Totais $12.800 \mathrm{mg} / \mathrm{L}$, Fixos $2.050 \mathrm{mg} / \mathrm{L}$ e Voláteis $10.750 \mathrm{mg} / \mathrm{L}$, próximo a outros valores de inóculo descritos na literatura1.

Em relação ao desempenho do reator, a remoção média de nitrogênio total, de amônia e de nitrito foram $15 \%$, $13 \%$ e $52 \%$, respectivamente.

Pelos resultados, observa-se que o reator não obteve plena capacidade de remoção de nitrogênio total, sendo aquém do esperado. Este fato se deve pelo início da operação, quando a biomassa ainda não está adaptada ao sistema e pela dificuldade de controle da entrada de oxigênio dissolvido (OD) junto com o afluente. Espera - se que, com algumas medidas de controle do OD e com a adaptação do inóculo ao afluente sintético, o reator tenha um melhor desempenho nos meses seguintes.

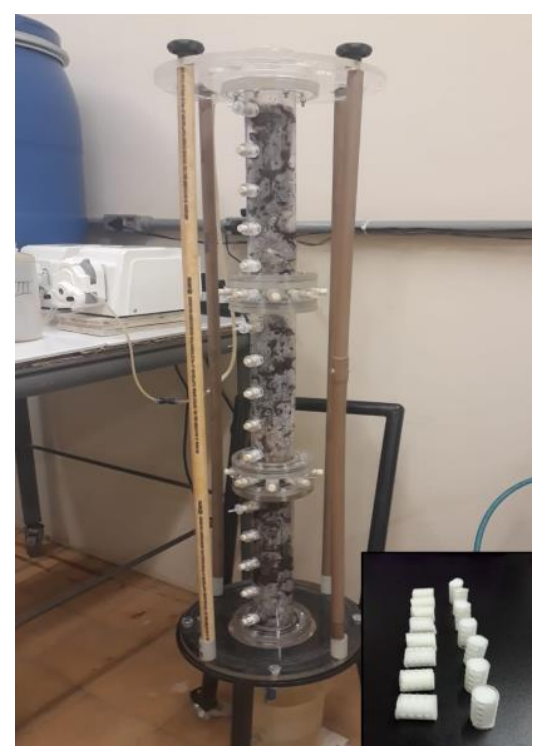

Figura 1. Reator Percolador e meio suporte ao lado.

\section{Conclusões}

O desempenho do reator foi aquém do esperado devido ao pouco tempo para adaptação da biomassa e a dificuldade de controle do OD no afluente sintético. Entretanto o trabalho foi importante para iniciar a pesquisa do grupo e caracterizar o inóculo que foi utilizado bem como o meio suporte do filtro biológico percolador.

\section{Agradecimentos}

Aos técnicos do LABSAN pelo suporte e dedicação no dia-a-dia, à UNICAMP e ao PIBIC pela concessão de bolsa.

1 BELLI FILHO, P. K.; SOARES, H. M.; MATIAS, W. G.; PINTO, R. O.; CHAGAS, A.; CASTILHO JR, A. B.; (2002) Digestão anaeróbia de resíduos sólidos orgânicos e lodo de tanque séptico; In: VII TALLER Y SIMPOSIO LATINO AMERICANO SOBRE DIGESTION ANAEROBIA, Mexico: IWA/FEMISCA. V.1 p.266-269. 